\title{
Effects of Sustainable Soil Management Practices on Distribution of Soil Organic Carbon in Upland Agricultural Soils of Mid-hills of Nepal
}

\author{
Ngamindra Dahal and Roshan M. Bajracharya \\ Kathmandu University \\ Dhulikhel, Kavre \\ e-mail: ngamindra@gmail.com
}

\begin{abstract}
An abundance of soil organic carbon (SOC) generally enhances the quality of lands for agriculture or forestry. Concentration of SOC varies in accordance to the type of land use, the inputs to the soil, and natural factors including climate and vegetation. SOC is vital for sustaining agricultural productivity which chiefly depends on both the inherent soil type and crop management practices affecting depletion or replenishment of organic matter over the years. Assessment of SOC concentration is a characteristic measurement of evaluating soil quality and the carbon sequestration potential of agricultural land. This study aims to assess SOC distribution on selected farmlands of Nepal's mid-hills, where farmers have adopted sustainable soil management practices in non-irrigable hill terraces ("Bari” land) in comparison with those of surrounding Bari and forests where no such interventions are made. Thus the present study estimated SOC content of three types of land use - farmland with sustainable soil management practices (SSMP), farmland without sustainable management practices (Non-SSMP) and the community managed forest in four mountain districts of Nepal, namely Baglung, Dhading, Kavre and Okhaldhunga. This study found the average SOC stocks in the SSMP land in the range of 20 - $44 \mathrm{Mgha}^{-1}$, those in non-SSMP agricultural areas 15 to $48 \mathrm{Mgha}^{-1}$, and in the forested land 16 to $23 \mathrm{Mgha}^{-1}$. In general, the abundance of SOC stocks are in the order of SSM $>$ Non-SSM $>$ Forests. The analysis indicates the high potential for carbon sequestration in hill agriculture lands through sustainable soil management.
\end{abstract}

Key Words: mountain farmers, non-irrigable agriculture land, soil organic carbon stock

\section{Introduction}

Agriculture lands rich in soil organic matter have important productivity and resilience benefits. These benefits include improvement in soil quality, increase in use-efficiency of inputs, reduction in soil erosion and sedimentation, and decrease in non-point source pollution. Lal (2004b) points out that soil organic carbon generally depletes through: (1) the long-term use of extractive and intensive farming practices, and (2) the conversion of natural ecosystems (such as forest lands, prairie lands, and steppes) into croplands and grazing lands. Such a conversion depletes the soil organic carbon pool by increasing the rate of conversion of soil organic matter to carbon dioxide (CO2), thereby reducing the input of biomass carbon and accentuating losses by erosion.
Being an agriculture-dominated country, a significant number of mountain farmers in Nepal have used farmyard manure (FYM) as the major source of plant nutrients based on traditional knowledge and techniques followed for generations. In the past, this contributed to the maintenance of a balanced inputoutput ratio of soil organic matter. According to Maskey et al. (2002), the majority of farmers (> 85\%) apply farmyard manure and/or compost in their fields. Gami et al. (2001) and Upadhyay et al. (2005) observed a decline in the soil organic carbon stocks due to changes in land use, intensive cultivation, and poor management of manure. A review by Dahal \& Bajracharya (2011) also revealed that in recent years, majority of farmers have switched to conventional usage of chemical fertilizers and intensified cropping 
systems as much as 3 or 4 crops per year, though a significant of farmers still rely upon compost or FYM, made of forest litter, crop residues as well as animal manure to replenish croplands, and followed a less intensive and more sustainable fallow farming system, producing only two crops in an annual cropping cycle.

Atreya et al. (2006) reported that soil erosion and intensive tillage in mid-mountain farmlands of Nepal led to a loss of soil organic carbon (SOC) $188 \mathrm{Kg} \mathrm{ha}^{-1} \mathrm{y}^{-1}$ in the farmlands under conventional tillage practice while the same was $126 \mathrm{Kg} \mathrm{ha}^{-1} \mathrm{y}^{-1}$ under non-conventional tillage practice. The study also noted that reduced tillage could be a viable strategy to reduce SOC loss, and thereby, reducing carbon dioxide $\left(\mathrm{CO}_{2}\right)$ emissions while saving plant nutrients in the soil. Sitaula et al. (2004) confirmed that SOC loss due to soil erosion is the major source of $\mathrm{CO}_{2}$ emissions from soil. This implies that control of soil erosion from farmlands is important in reducing SOC losses eventually then emissions of $\mathrm{CO}_{2}$.

Likewise, Shrestha et al. (2004) reported similar results in a mountain watershed of Nepal, and related SOC to FYM input by the farmers. The growth and function of vegetation depends on the availability of plant nutrients in the soil, whilst SOC distributions depend on the input received from the vegetation grown. The input can be from above-ground leaf litter and/or the below-ground ûne roots (Bloomûeld et al. 1996) and their decomposition rates are governed by microbial activity. The chemical composition of vegetation determines the residence time of organic carbon in the terrestrial ecosystem (Rasse et al. 2006). High SOC is a characteristic of soil conditions and structure that create a favorable habitat for plants. Singh (2007) estimated total stocks of organic carbon in aboveground and below-ground in the three Indian Himalayan states, namely, Jammu Kashmir, Uttarakhand and Himachal Pradesh, to be around 700 metric ton $\mathrm{C}$ ha-1.

Bajracharya (2002) noticed that there has been a notable shift in recent cropping patterns due to increasing food and cash-crop demands along with availability of agro-chemicals though supplies are often interrupted. This has led to diminishing productivity and fertility of arable lands. The main reasons for low yields are believed to be the lack of replenishment of soil organic matter and soil nutrients, and inadequate or inappropriate use of fertilizers (Bajracharya 2002, Regmi et al. 2005, Karki 2006).
Unlike the conventional agricultural practices that often lead to impoverishment of soil quality and reduced productivity of lands, locally improved techniques such as sustainable soil management practices, adopted by farmers in selected parts of mountain districts of Nepal, are reported to be a remedy to the problems of fertility and productivity decline (SSMP, 2009). Some key features of the sustainable soil management (SSM) approach (SSMP 2009) are reported as follows:

a) Improvement in the quality of farm yard manure (FYM) through a five step action plan:

i) maintenance of a well-managed heap or pit properly protected from the sun using a protective cover, usually plastic, bamboo or foliage roof;

ii) protection from the rain, run-in and run-on water;

iii) proper drainage, collection, and storage of cattle urine through simple redesign to, or improvement of, the cattle shed;

iv) regular aeration of the FYM through use of a prod or pole, and maintenance of the FYM in a slightly moist condition before carrying it to the field;

v) no exposure to the sun of the small FYM heaps in the field prior to application - again covering is crucial.

b) The use of cattle urine as a fertilizer, plant tonic and bio-pesticide.

c) The combining of the above practices with inclusion of legumes, fodder, and forage plants into the rotation.

d) The incorporation of vegetables and other cash crops into the cropping systems.

The key research question of this study is: what is the difference in SOC status between the agriculture lands where improved soil management practices are applied, and those of conventional one where no such practices are adopted? Answering this question requires a comprehensive understanding of the dynamics of Nepal mountain farming systems in which forests are an integral part. This study has attempted to address the research question by analyzing the SOC status in the three land use categories - non-irrigable upland agriculture land (bari) with sustainable soil management practices (SSMP), non-irrigable upland agriculture land (bari) with conventional soil 
management practices (Non-SSMP) and community managed forests (local forest). A review of past studies undertaken in Nepal mid hills and other parts of the Himalaya provide a useful reference for enhancing knowledge of agriculture soil dynamics and emissions of carbon dioxide from agriculture lands.

\section{Methodology}

Farm fields were sampled for collection of soil (core and composite) samples from 0-15, 15-30, 30-60, and 60-100 cm depths, or down to the bed rock from three types of land: non-irrigable agriculture land (bari) with sustainable soil management practices (SSMP), bari with conventional soil management practices (NonSSMP) and community managed forests (local forest). Bari or rain-fed upland terraces where SSM practices were performed were first chosen. As control sites, surrounding bari lands were chosen where no-SSM practices were performed. Likewise, samples were taken from the forests on which the SSM practicing households depend for their household, livestock and farm needs. The sampled points were recorded using handheld GPS (geographic positioning system) equipment for reference, and permitting the sites to be re-sampled in the future.

\section{Selection of research sites}

Among the 15 SSM programme districts where the Helvetas-Intercooperation-funded Sustainable Soil Management Programme (SSMP) was implemented, Baglung, Dhading, Kavre and Okhaldhunga districts were chosen for this study. The purpose of selecting these also to capture optimum geographical coverage along the mountain region where a significant population size of farmers who are dependent on bari (non-irrigable upland agriculture lands) still exists. One VDC (village development committee) of each district was chosen for sampling where clusters of SSMpracticing households exist. The information and database from the Helvetas Swiss Intercooperationfunded Sustainable Soil Management Programme (SSMP) were instrumental in identifying the research plots. The database included the names of farmers, location, type of land, and the years of participation in the programme. Once the SSM plots were identified, the non-SSM and forests plots were chosen locally taking SSM plots as a reference.

\section{Field sampling methods and size}

Soil samples were collected and analyzed systematically from the three categories of land namely, SSMP farmlands, conventional farmlands (non-SSMP), and community-managed forest in the four districts of Nepal. The land categories were characterized by measurement of three major parameters: SOC, bulk density and soil type. During sample collection, details of soil profile, field conditions and GPS locations of the site were recorded. The collected soil samples from each farm plot were tested at the ISO accredited Aquatic Ecology Centre Soil and Water Analysis Laboratory at Kathmandu University using standard methods. Statistical data analysis techniques (ANOVA, correlation, regression) were employed to interpret the results.

All together 127 samples were collected from four districts (Table 1). In each of these districts, three plots were identified in SSMP, non-SSMP and forestlands. For each plot, there were four replications of $1 \mathrm{~m}$ depth or down to rock whichever came first. Of the $1 \mathrm{~m}$ thickness of soil, four layers were sampled, $0-15 \mathrm{~cm}$, $15-30 \mathrm{~cm}, 30-60 \mathrm{~cm}$ and $60-100 \mathrm{~cm}$. Thus, the total sample size was the product of 4 districts $* 3$ plots $* 4$ replications*4 layers, a total of 192 . While collecting actual samples, however, only 127 were available because a number of sampled plots were of shallow depth, far less than the maximum depth of $100 \mathrm{~cm}$. In fact, the average thickness of the majority of the selected forest plots were up to $30 \mathrm{~cm}$ whereas those in SSMP and non-SSMP were up to $60 \mathrm{~cm}$.

Table 1. Sample size distribution by depth wise and types of land use- forest, SSMP and NonSSMP

\begin{tabular}{|c|c|c|c|c|c|}
\hline Depth & Frequency & Percent & Land use type & Frequency & Percent \\
\hline 0-15 & 43 & 34 & SSMP & 46 & 36 \\
\hline $15-30$ & 42 & 33 & Non-SSMP & 47 & 37 \\
\hline $30-60$ & 27 & 21 & Forest & 34 & 27 \\
\hline $60-100$ & 15 & 12 & & & \\
\hline Total & 127 & 100 & Total & 127 & 100 \\
\hline
\end{tabular}

Calculation of soil carbon pool

The total pool of soil carbon (TPSC) is expressed as Mega grams per hectare for a specific depth, and was computed as a product of $\mathrm{C}$ concentration, bulk density, and depth (Pearson et al. 2007) as follows:

TPSC $=$ SC/1000X BDX SD X10000 $\mathrm{Mg} \mathrm{ha}^{-1}$

Where TPSC = total soil carbon pool, $\mathrm{Mg} \mathrm{ha}^{-1}$, $\mathrm{SC}=$ concentration of soil $\mathrm{C}, \mathrm{gkg}^{-1}$ soil, $\mathrm{BD}=$ bulk density, $\mathrm{gcm}^{-3}$, and $\mathrm{SD}=$ soil depth, $\mathrm{m}$. 
In addition to other essential properties, soil bulk density and carbon concentration were assessed. The carbon stocks in the soil profiles under different land uses were then estimated. The findings were analyzed in comparison with those of similar other studies in the past such as the one by Bajracharya \& Atreya (2007).

\section{Results and analysis}

In this section, analyses of the results are interpreted in terms of soil bulk density, SOC concentration and estimation of SOC stocks (volume) in the respective sampled plots. Correlation of SOC distribution with respect to physical and chemical characteristics of soils, namely, soil texture (clay, silt \& sand), $\mathrm{pH}$ value, conductivity and potassium (K) were performed. These results are compared with relevant past studies published in various journals and conference proceedings as applicable.

\section{Soil bulk density}

Soil bulk density (BD) indicates compactness of soil which is essential to estimate SOC volume. Of the sampled plots, the mean $\mathrm{BD}$ was $1.2 \mathrm{gcm}^{-3}$ while the minimum and maximum values were $0.79 \mathrm{gcm}^{-3}$ and $1.56 \mathrm{gcm}^{-3}$. Among the three land categories - SSMP, Non-SSMP and forest, the mean BD was essentially the same for SSMP and Non-SSMP with the values of $1.25 \mathrm{gcm}^{-3}$ and $1.23 \mathrm{gcm}^{-3}$, but lower in the forest soils with $1.11 \mathrm{gcm}^{-3}$. This implies that soils were more compact in the agricultural lands compared to those of adjacent forests. Also, lower BD in the surface layer forest soils can be expected due to higher SOM contents compared to agricultural soils. Analysis of the samples also confirmed a steady increase of BD values from top to bottom layers with $1.17,1.19,1.25$ and $1.28 \mathrm{gm} / \mathrm{cm}^{-}{ }^{3}$, respectively from $0-15,15-30,30-60$ and $60-100 \mathrm{~cm}$ depths. This is consistent with general principles of soil compactness - the deeper the layer the denser the soil.

The mean BD values among the SSMP, Non-SSMP and forest are $1.17,1.21$ and $1.13 \mathrm{gcm}-{ }^{3}$ respectively. This indicates that the soils of the top layer in SSMP and forest are less compact than non-SSMP. However, in the deeper layers, the BD (or compactness) of SSMP soils is higher than non-SSMP and forest. This was likely due to the fact that the effect of SSM practices was limited to the topsoil, but these effects were not seen at greater depths in the profile.

\section{Spatial distribution of SOC}

Analysis of the SOC survey data revealed that the mean concentration of SOC across the sampled plots was $1.5 \%$. Among the three categories of land use, the mean SOC is highest in the SSMP plots (1.7\%) followed by the forest plots (1.3\%), and then the nonSSMP plots (1.2\%). Based on individual samples, the highest concentration (3.68\%) was observed in an SSMP plot while the lowest $(0.19 \%)$ was noted in a non-SSMP plot. There was a steady decline of SOC concentration from surface to deeper layers as recorded in table 2 . The mean concentration of the 0 $15 \mathrm{~cm}$ layer is $1.85 \%$; this declines to $1.13 \%$ at the lower layer of $60-100 \mathrm{~cm}$. The rapid decrease of the sample count towards the lower layers was evident in the case of forest soils where the majority of plots are less than $30 \mathrm{~cm}$ depth. The count of forests samples from 0-15 cm layer to 30-60 cm layer dropped from 14 to 3 indicating the shallow nature of the forest soils. Furthermore, no forest soil samples were taken in the 60-100 cm layer in forest. For the SSMP and nonSSMP plots, the number of samples recorded for the deepest layer $(60-100 \mathrm{~cm})$ was nearly half that of the top layers.

SOC concentration was generally higher in the forest top soils compared to agriculture land, although the

Table 2. Distribution of SOC concentration across depth in SSMP, Non SSMP and Forest lands

\begin{tabular}{|c|c|c|c|c|c|c|c|c|c|c|c|c|c|}
\hline \multirow{3}{*}{$\begin{array}{l}\text { Soil } \\
\text { Depth } \\
(\mathrm{cm})\end{array}$} & \multicolumn{12}{|c|}{ SOC concentration (\%) in the three land use type } & \multirow{3}{*}{$\begin{array}{l}\text { Depth } \\
\text { wise } \\
\text { mean }\end{array}$} \\
\hline & \multicolumn{4}{|c|}{ SSMP } & \multicolumn{4}{|c|}{ Non-SSMP } & \multicolumn{4}{|c|}{ Forest } & \\
\hline & Count & Min & Max & Mean & Count & Min & Max & Mean & Count & Min & Max & Mean & \\
\hline $0-15$ & 14 & 0.92 & 3.38 & 2.1 & 14 & 1.2 & 2.22 & 1.7 & 14 & 1.3 & 2.69 & 1.9 & 1.85 \\
\hline $15-30$ & 14 & 0.45 & 3.09 & 1.7 & 14 & 0.9 & 3.68 & 1.5 & 13 & 0.83 & 2.65 & 1.5 & 1.54 \\
\hline $30-60$ & 12 & 0.29 & 2.26 & 1.6 & 12 & 0.89 & 2.29 & 1.3 & 3 & 1.6 & 2.49 & 1.9 & 1.45 \\
\hline $60-100$ & 8 & 0.75 & 2.04 & 1.4 & 7 & 0.19 & 1.85 & 0.9 & Nil & Nil & Nil & Nil & 1.13 \\
\hline \multicolumn{4}{|c|}{ Mean of land use category } & 1.7 & & & & 1.2 & & & & 1.3 & 1.5 \\
\hline
\end{tabular}


N. Dahal \& R.M. Bajracharya/Effects of Sustainable.......

fact that the forest soils in the hills are shallow (often no more than the depth of $30 \mathrm{~cm}$ ) limits the prospect of storing large SOC stocks. On the other hand, a deeper soil profile allows the agriculture lands to have larger overall SOC stocks despite the lower concentration level.

Table 2 data shows the mean SOC concentration is $1.5 \%$. These results were comparable to a similar study by Bajracharya (1999) in central Nepal, that estimated $1.8 \%$ SOC concentration in the rain-fed upland and $4 \%$ in forest. Another study by Balla et al. (2000) estimated SOC concentration in the rain-fed agriculture lands of Kali Khola Watershed and Andheri Khola Watershed in the range of 0.8 to $1.4 \%$ and 0.75 to $1.1 \%$, respectively. However, in the forests, the SOC concentrations were significantly higher ranging between 1.4 to $4.6 \%$. Likewise, Vaidya et al. (1995) in the western hills of Nepal found $1.2 \%$ in rain-fed agricultural land. Research undertaken by Bontalakoti et al. (2000) in a rain-fed agriculture field of the Indian Himalaya found $1.7 \%$ concentration of SOC, which is similar to the finding of this research.

\section{Total SOC stock}

Based on the SOC survey in the four districts, namely, Baglung, Dhading, Kavre and Okhaldhunga, the average SOC stocks in the SSMP land were in the range of 20 - $44 \mathrm{Mgha}^{-1}$. In non-SSMP and locally managed forests, the ranges are $15 \mathrm{Mgha}^{-1}-38 \mathrm{Mg}$ $\mathrm{ha}^{-1}$, and 16 - $23 \mathrm{Mgha}^{-1}$, respectively. There were significant differences of SOC stocks across four depth layers from $0 \mathrm{~cm}$ to $100 \mathrm{~cm}$. However, the orders of differences were non-uniform. In the case of the top layer $(0-15 \mathrm{~cm})$, the SOC stocks in SSMP ranged between $22 \mathrm{Mgha}^{-1}$ and $47 \mathrm{Mgha}^{-1}$, in non-SSMP between $23 \mathrm{Mgha}^{-1}$ and $39 \mathrm{Mgha}^{-1}$ and, in the case of forests the same was between $\mathrm{Mgha}^{-1} 25$ and 42 Mgha $^{-1}$. In general, the order of richness of SOC stocks was SSM $>$ Non-SSM $>$ Forests with few exceptions (Table 3). This was also true among soil layers as the majority of sampled sites showed higher SOC levels than the respective lower one.

Of the $100 \mathrm{~cm}$ depth of soil, which was categorized into four layers $(0-15 \mathrm{~cm}, 15-30 \mathrm{~cm}, 30-60 \mathrm{~cm}$ and $60-100 \mathrm{~cm}$ from the top), SOC pools, as anticipated, again generally followed the trend of being high in the top layers, and, gradually decreasing to the deeper layer or higher depth. However, there were a few exceptions, possibly due to mixing and incorporation of organic matter during tillage or terrace formation.

Table 3. SOC Stocks in Four Districts of Nepal.

\begin{tabular}{l|c|c|c|c|c}
\hline \multirow{2}{*}{ Baglung } & \multicolumn{5}{|c}{ SOC Stock (Mgha-1 $)$} \\
\cline { 2 - 6 } & $0-15 \mathrm{~cm}$ & $15-30 \mathrm{~cm}$ & $30-60 \mathrm{~cm}$ & $60-100 \mathrm{~cm}$ & Mean \\
\hline SSMP & 39 & 32 & 42 & 15 & 29 \\
Non SSM & 36 & 34 & 54 & 80 & 48 \\
Forest & 33 & 28 & 30 & 0 & 23 \\
\hline Dhading & & & & & \\
SSMP & 29 & 25 & 53 & 71 & 45 \\
Non SSM & 22 & 11 & 32 & 17 & 20 \\
Forest & 25 & 39 & 0 & 0 & 16 \\
\hline Kavre & & & & & \\
SSMP & 27 & 34 & 44 & 27 & 33 \\
Non SSM & 23 & 23 & 15 & 0 & 15 \\
Forest & 37 & 31 & 0 & 0 & 17 \\
\hline Okhaldhunga & & & & & \\
SSMP & 47 & 39 & 48 & 42 & 44 \\
NonSSM & 39 & 35 & 62 & 0 & 34 \\
Forest & 42 & 33 & 0 & 0 & 19 \\
\hline
\end{tabular}

Field Survey, 2011.

As shown in the above table, the mean SOC stock per ha, down to $100 \mathrm{~cm}$, varied spatially according to landuse type; the highest record level was in non-SSMP land (48 $\mathrm{Mg} \mathrm{ha}^{-1}$ ) in Baglung, followed by SSMP lands in Dhading (45 $\mathrm{Mg} \mathrm{ha}^{-1}$ ) and Okhaldhunga (43 Mg $\left.\mathrm{ha}^{-1}\right)$. In the case of Kavre, SSMP and non-SSMP stocks are $33 \mathrm{Mg} \mathrm{ha}^{-1}$ and $15 \mathrm{Mg}$ ha $^{-1}$ respectively which is a significant difference. Thus, the spatial distribution of different land uses was also reûected in the SOC pools.

\section{Correlations between SOC and key soil characteristics}

Table 4 shows the SOC correlations with other physical and chemical parameters - namely, bulk density (BD), soil moisture content (SMC), cation exchange capacity (CEC), soil texture (clay, sand, silt), $\mathrm{pH}$, potassium (K) and soil depth. The correlation chart reveals that the correlation between SOC abundance and clay-rich soil is highly significant, and analyses clearly show a significant positive correlation of SOC concentration with $\mathrm{pH}$ value. This indicates that higher SOC concentrations have a beneficial effect on soil $\mathrm{pH}$. Likewise, there are significant positive correlations of 
cation exchange capacity and potassium with SOC, indicating that higher SOC levels have a positive effect on CEC and potassium content.

On the other side, there is significant negative correlation of depth and SOC concentration, clearly indicating that the deeper soil layers have lower SOC. This is as expected since organic matter move down rather slowly to the deeper soil profile. On the contrary, SOC concentration declines in sandy soils as reflected by the highly significant negative correlation with sandy soils. This reflects the fact that SOC tends to accumulate in clay soils. In relation to potassium distribution, a significant positive correlation with SOC was observed, presumably because the potassium, a highly mobile ion, attaches itself to the exchange sites of the organic matter.

The results presented in the table 4 demonstrate significant correlations of SOC with other major chemical and physical parameters, which are preferable for agriculture soil. The abundant SOC of a soil naturally enhances CEC and neutralizes pH level. The negatively significant correlations of SOC with bulk density indicate that rich SOC make soil friable and less compact, which is a desirable condition for agricultural land. However, the SOC impacts on soil moisture content (SMC) could not be established as there is no significant correlation between SMC and SOC.

\section{Resutls and Discussion}

The key finding of this study is the distribution scenario of SOC stocks across the four hill districts of Nepal. Analysis by district wise shows that all SSMP lands hold higher SOC stocks compared to non-SSMP and forests soils in all districts. One important point noticed through this analysis is the difference between SOC concentration and SOC stocks. SOC pools or stocks represent the total volume of organic carbon stored in the given depth per unit area of land, while the concentration of SOC measures its richness in the given sample as expressed in \% or gkg-1. SOC stocks are thus the product of SOC concentration, and area, and depth of the sample. In the case of forests, despite high SOC concentration, the stocks were lower than

Table 4. Correlations analysis for the major physical and chemical characteristics of sampled soils.

\begin{tabular}{|c|c|c|c|c|c|c|c|c|c|}
\hline \multicolumn{2}{|c|}{ Parameters } & $\mathrm{BD}$ & SMC & Clay & Sand & Silt & $\mathrm{pH}$ & SOC & Depth \\
\hline SMC & $\begin{array}{l}\text { Correlat. } \\
\mathrm{N}\end{array}$ & $\begin{array}{l}0.057 \\
127\end{array}$ & & & & & & & \\
\hline Clay & $\begin{array}{l}\text { Correlat. } \\
\mathrm{N}\end{array}$ & $\begin{array}{l}0.098 \\
127\end{array}$ & $\begin{array}{l}.301(* *) \\
127\end{array}$ & & & & & & \\
\hline Sand & $\begin{array}{l}\text { Correlat. } \\
\mathrm{N}\end{array}$ & $\begin{array}{l}-0.087 \\
127\end{array}$ & $\begin{array}{l}-.293(* *) \\
127\end{array}$ & $\begin{array}{l}-.479(* *) \\
127\end{array}$ & & & & & \\
\hline Silt & $\begin{array}{l}\text { Correlat. } \\
\mathrm{N}\end{array}$ & $\begin{array}{l}-0.031 \\
127\end{array}$ & $\begin{array}{l}-0.071 \\
127\end{array}$ & $\begin{array}{l}-.660(* *) \\
127\end{array}$ & $\begin{array}{l}-.344(* *) \\
127\end{array}$ & & & & \\
\hline $\mathrm{pH}$ & $\begin{array}{l}\text { Correlat. } \\
\text { N }\end{array}$ & $\begin{array}{l}270(* *) \\
127\end{array}$ & $\begin{array}{l}.276\left(^{* *}\right) \\
127\end{array}$ & $\begin{array}{l}.360(* *) \\
127\end{array}$ & $\begin{array}{l}-.187\left(^{*}\right) \\
127\end{array}$ & $\begin{array}{l}-.225\left(^{*}\right) \\
127\end{array}$ & & & \\
\hline SOC & $\begin{array}{l}\text { Correlat. } \\
\mathrm{N}\end{array}$ & $\begin{array}{l}-.343(* *) \\
126\end{array}$ & $\begin{array}{l}-\mathbf{0 . 0 1 7} \\
126\end{array}$ & $\begin{array}{l}.267(* *) \\
126\end{array}$ & $\begin{array}{l}-.231(* *) \\
126\end{array}$ & $\begin{array}{l}-\mathbf{0 . 0 8 8} \\
126\end{array}$ & $\begin{array}{l}.213(*) \\
126\end{array}$ & & \\
\hline Depth & $\begin{array}{l}\text { Correlat. } \\
\mathrm{N}\end{array}$ & $\begin{array}{l}236(* *) \\
127\end{array}$ & $\begin{array}{l}.187\left(^{*}\right) \\
127\end{array}$ & $\begin{array}{l}.320\left(^{* *}\right) \\
127\end{array}$ & $\begin{array}{l}-0.083 \\
127\end{array}$ & $\begin{array}{l}-.271(* *) \\
127\end{array}$ & $\begin{array}{l}0.169 \\
127\end{array}$ & $\begin{array}{l}-.347(* *) \\
126\end{array}$ & \\
\hline CEC & $\begin{array}{l}\text { Correlat. } \\
\mathrm{N}\end{array}$ & $\begin{array}{l}-0.142 \\
85\end{array}$ & $\begin{array}{l}.224(*) \\
85\end{array}$ & $\begin{array}{l}0.074 \\
85\end{array}$ & $\begin{array}{l}-.336 \\
(* *) \\
85\end{array}$ & $\begin{array}{l}0.194 \\
85\end{array}$ & $\begin{array}{l}0.105 \\
85\end{array}$ & $\begin{array}{l}-0.157 \\
85\end{array}$ & $\begin{array}{l}-0.129 \\
85\end{array}$ \\
\hline K & $\begin{array}{l}\text { Correlat. } \\
\text { N }\end{array}$ & $\begin{array}{l}0.008 \\
83\end{array}$ & $\begin{array}{l}-0.032 \\
83\end{array}$ & $\begin{array}{l}.275\left(^{*}\right) \\
83\end{array}$ & $\begin{array}{l}0.125 \\
83\end{array}$ & $\begin{array}{l}-.377(* *) \\
83\end{array}$ & $\begin{array}{l}.470(* *) \\
83\end{array}$ & $\begin{array}{l}.333(* *) \\
83\end{array}$ & $\begin{array}{l}-0.038 \\
83\end{array}$ \\
\hline
\end{tabular}

** Correlation is significant at the 0.01 level (2-tailed). * Correlation is significant at 0.05 level (2-tailed). Field Survey, 2011. 


\section{N. Dahal \& R.M. Bajracharya/Effects of Sustainable.......}

the other two land use types - this is mainly because of the shallow soil depth of forest areas which are often limited to steep mountain slopes. On the contrary, the SOC stocks are high in agriculture soils, despite lower concentrations of SOC compared to the forests, mainly because of greater soil depth. In forests, most of the samples were available only up to $30 \mathrm{~cm}$ (or two layers), while the majority of agriculture lands had three layers of samples (up to $60 \mathrm{~cm}$ ), and some up to $100 \mathrm{~cm}$.

The range of SOC stocks in different landuse and land management categories is close to the findings of similar past studies conducted in the hilly regions. Bajracharya et al (2004) estimated SOC stocks in the mid-hills of Nepal at approximately $423.7 \mathrm{Mt}$ C; the study also found SOC concentration lower in the nonirrigable upland or bari which was between 1 and $2 \%$. In the irrigable land, however, the SOC concentration was somewhat higher in the range between 1.5 to $2.6 \%$. The study also shows the concentration of SOC in forest and shrub land (2.0\% and $2.3 \%$ respectively) higher than those of cultivated land in the top layer (1-30 cm). Shrestha \& Singh (2008) found higher SOC stocks in the rain-fed upland (bari) compared to irrigated low land (khet), which is attributed primarily to fertilizer and FYM inputs by the farmers as they tend to apply more FYM to bari lands due to the proximity to their homesteads. The same study which was conducted in Pokhare Khola Watershed found SOC stocks in the non-irrigable upland (bari) in the order of $15.7 \pm 1.5 \mathrm{~kg} \mathrm{C} \mathrm{m}^{-2}$. The study also compared the stocks among various land use types and found the results in the order of bari $>$ dense forest $>$ khet $>$ mix forest $>$ degraded forest. Depth wise, the total SOC stock in the whole watershed was distributed through the profile as follows: $36 \%, 32 \%$, and $32 \%$ in the $0-20$, 20-40, and $>40 \mathrm{~cm}$ depth range respectively.

A study by Bajracharya et al (2007) substantiated the prospect of benefiting Nepali farmers from SSM practices by estimating total SOC in upland agriculture lands of Nepal. The study put the final figure of total SOC to be around 37.8 million metric ton, which is based on CBS data (2003) that shows total upland agricultural land in Nepal covers a little more than one million hectares. To calculate the total amount of SOC stored in the hills, the land area was multiplied by the average carbon density. The study also put the figures of market value of the SOC to be between US \$ 4.43 and 7.25 million on the basis of a rate of US\$ 2.5 per ton C. Further to this study, Bajracharya \& Sherchan (2009) pointed out that restoring SOC along with other nutrients in the mountain agriculture lands of the Himalaya is essential for food security as well as reducing greenhouse gas emissions from soils. Temperature and moisture, which vary with altitude, are major climatic factors responsible for determining the decomposition rate of organic carbon (Amundson 2001). Chhabra et al. (2003) reported SOC stocks (1m depth) in Indian forests between $70 \mathrm{Mg} \mathrm{ha}^{-1}$ to $162 \mathrm{Mg} \mathrm{ha}^{-1}$, which are significantly higher than those found in this study (16 to $23 \mathrm{Mgh}^{-1}$ ). The differences may be attributed to the shallow soil of Nepali forest ecosystems selected for this study, which are mostly within $30 \mathrm{~cm}$ depth and only few up to $60 \mathrm{~cm}$.

Bajracharya (2006) estimated that nearly $80 \%$ of the demand of chemical fertilizers and pesticides can be reduced through applications of farmyard manure and compost along with urine collection and application and the use of organic bio-pesticides. This study revealed that in the 15 programme districts, where the average land holding is 0.62 hectare, the total amount of SOC stored in the SSMP improved FYM household's land has been estimated as ranging from 1.77 million tons to 2.90 million tons. Intensive tillage and continuous removal of biomass from agricultural fields often lead to gradual decline of SOC. Beyond the local and national scale, Lal (2004a) recommended for adoption of recommended management practices (RMPs) for reducing soil losses from degraded soils. Furthermore, the study revealed that technical potential of soil organic carbon sequestration through adoption of RMPs for world cropland soils (1.5 billion hectares) is 0.4 billion to 1.2 billion metric ton of carbon per year.

Thus, enhancing soil organic carbon involves adding the maximum amount of soil organic matter to the soil. SSMP is one such approach for converting degraded soils into restored land that also contributes to increasing the soil carbon pool. While no single technology is appropriate for all soils, climates, or cropping and farming systems, the goal then should be to identify site-specific technologies that create a positive soil carbon budget. For example, ICIMOD (2008) have enlisted 9 different approaches of improved agro-practice management and 21 technologies as effective ways for improving livelihood of low income farmers of mid hill Nepal, but the same 
Nepal Journal of Science and Technology Vol. 13, No. 1 (2012) 133-141

are not analyzed from the perspective of GHG gas emissions.

In the Nepal, mountain farmers traditionally use locally prepared compost and manure, from forest litter, agricultural waste and animal dung, in a regular manner and this enriches the soil organic carbon. In the rainfed agriculture land of hill regions, the replenishment of soil organic matter is usually poor where farmers tend to harvest crop grain along with straw leaving behind only roots. Gradual loss of SOC contents lead to impoverishment of the soil. Removal of SOC from a soil ultimately leads to the emission of $\mathrm{CO}_{2}$ into the atmosphere. Contrary to this, inputs of biomass in the forms of farmyard manure consisting of forest litters, agricultural waste and animal dung contributes to enhanced soil organic matter levels. SOC is essentially the decomposed biomass of plant and animal material transformed and assimilated within the soil over years.

This study confirms that SOC stocks are higher in Bari lands compared to forested areas, and follow the order SSMP $>$ non-SSMP $>$ forest. Among the layers, the SOC stock was highest in the top layer followed by second, third and forth lower layers. The SOC distribution had significant correlations with clay content, potassium and $\mathrm{pH}$ value of the soil. However, the SOC abundance was negatively correlated with bulk density, sand content and depth. The study confirmed that well managed bari lands with SSMP approaches can be more effective than conventional farming practices in accumulating organic carbon in the soil.

Analysis of SOC pools between Bari with and without SSM practices revealed that the former consists of higher SOC stocks than the latter. The forested land had the least total SOC stock despite generally higher SOC contents in the surface layer (topsoil) - this is due to shallow soil depth. Among the three land types, the mean SOC concentration was highest in SSMP areas $(1.7 \%)$, followed by the forested areas $(1.3 \%)$, and the non-SSMP areas (1.2\%). Likewise, the SOC stocks in the top layer $(0-15 \mathrm{~cm})$ were between 22 Mgha1 and 47 Mgha- 1 in the SSMP category, between 23 Mgha-1 and 39 Mgha-1 in the non- SSMP areas, and between Mgha-1 25 and 42 Mgha-1 in forested soils.

This study confirmed that the effects of SSM practices will create not only favorable soil conditions in agriculture lands, but also enhance stocks of SOC which will help in addressing the global concern of reducing carbon dioxide emissions from the agriculture sector. The policy implications of these findings are that the agriculture sector should attempt to access global climate funds in return for the adoption of SSM practices as one measure that can contribute to mitigating greenhouse gas emissions.

\section{Acknowledgements}

The authors acknowledge the support provided by the Helvetas Swiss Intercooperation-funded Sustainable Soil Management Programme (SSMP) particularly Mr Richard Allen and his team for assisting in carrying out the field works. The authors would also like to thank Mr Santosh Dahal for assisting in the field works, and Ms Rosa Rout and Ms Urshula Bajracharya of Kathmandu University for their support during the laboratory testing of soil samples.

\section{References}

Amundson, R. 2001. The carbon budget in soils (Review). Annual Review of Earth Planet Science 29:535-562.

Atreya, K., S. Sharma, R.M. Bajracharya and N.P. Rajbhandrary. 2006. Applications of reduced tillage in the hills of Nepal. Soil and tillage research 88:16-29.

Bajracharya, R.M. and K. Atreya. 2007. Carbon sequestration in the upland farming systems in Nepal Midhills. In: Proceedings of Conference on Environment (June 22-24, 2007). Tribhuvan University, Nepal.

Bajracharya, R.M. and D.L. Sherchan. 2009. Fertility status and dynamics of soils in the Nepal Himalaya: A review and analysis. In: Soil Fertility. (Eds. D. P. Lucero \& J. E. Boggs). Nova Science Publishers, Inc.

Bajracharya, R.M. 2002. Fertility and productivity parameters for soil from five Mid-hill districts of central Nepal. In: Proceedings of International Seminar on Mountains. (March 6-8, 2002). Kathmandu: Royal Nepal Academy of Science and Technology. Pp 141150.

Bajracharya, R.M. 1999. Biodiversity conservation and economic development in the Phulchoki and Chandragiri hill areas: Soil conservation and agricultural aspects. Bagmati Integrated Watershed Management (BIWMP) Study Project Report. Ministry of Forest and Soil Conservation, Kathmandu.

Bajracharya, R.M., B.K. Sitaula, B.M. Shrestha, K.D. Awasthi, M.K. Balla and B.R. Singh. 2004. Soil organic carbon status and dynamics in the central Nepal: Middle mountains. Journal of Institute of Forestry. 12:28-44. Institute of Forestry, Pokhara, Nepal.

Balla, M.K., K.D. Awasthi, P.K. Shrestha, D.P. Sherchan and D. Poudel. 2000. Degraded lands in Mid-hills of 
N. Dahal \& R.M. Bajracharya/Effects of Sustainable.......

central Nepal: A GIS appraisal in quantifying and planning for sustainable rehabilitation. Local Initiatives for Biodiversity Research and Development (LIBIRD), Pokhara, Nepal.

Bloomûeld J, K. Vogt, and P.M. Wargo. 1996. Tree root turnover and senescence. In: Plant roots- the hidden half. (Eds. Y. Waisel, A. Eshel, U. Kafkaû). Marcel Dekker, Inc., New York. Pp 363-380.

Bontalakoti, K.R., K. Joshi, A.K. Mishra, B.P. Kothyari and R.K. Pande. 2000. Rainfall and soil erosion in the Bheta Gad watershed of Uttar Pradesh in the Central Himalayas. In: The people and resource dynamics project: First three years (1996-1999). (Eds. R. Allen, H. Schreier, S. Brown \& P.B. Shah). ICIMOD, Kathmandu, 199-207.

CBS. 2003. National Sample Census of Agriculture, Nepal, 2001/02: Highlights. Central Bureau of Statistics, Nepal.

Chhabra A, S. Palria and V.K. Dadhwal. 2003. Soil organic carbon pool in Indian forests. Ecology Management. 173 (1-3):187-199.

Dahal, N. and R.M. Bajracharya. 2011. Prospects of soil organic sequestration: Implications for Nepal's mountain agriculture. Journal of Forest and Livelihood. 9 (1). Forest Action, Kathmandu.

Gami, S., J. Ladha, H. Pathak, M. Shah, E. Pasuquin, S. Pandey, P. Hobbs, D. Joshy, R. Mishra. 2001. Longterm changes in yield and soil fertility in a twentyyear rice, wheat experiment in Nepal. Biology and Fertility of Soils. 34: 73-78.

ICIMOD. 2008. Natural Resource Management Approaches and Technologies in Nepal (NEPCAT Fact sheets). International Centre for Integrated Mountain Development. Kathmandu, Nepal.

Kaini, B.R. 2004. Increasing Crops Production in Nepal. In: Proceedings 24th National Summer Crops Research Workshop on Maize Research and Production in Nepal on (June 28 to 30, 2004), (Eds. D.P. Sherchan, K. Adhikari , B.K. Batsa \& D. Sharma). NMRP and NARC, Kathmandu, Nepal. Pp 15-19.

Karki, K.B. 2006. Impact of cropping intensification on nutritional balance in Nepalese soils. Proceedings of International Seminar on Environmental and Social Impacts of Agricultural Intensification in Himalayan Watersheds (October 15-17, 2006). Kathmandu, Nepal. Pp 27-33.

Lal, R. 2004a. Soil carbon sequestration impacts on global climate change and food security. Science 304: 16231627.

Lal, R. 2009. The potential for soil carbon sequestration. Agriculture and climate change: An agenda for negotiation in Copenhagen for food, agriculture and the environment. IFPRI Policy Brief 5. Pp 16 -22.

Lal, R. 2004b. Soil and forest degradation in South Asia.
Journal of Institute of Forestry Nepal. Pp 8-17.

Maskey, S; R.K. Shrestha, B. Shrestha, B.P. Tripathi, E.M. Bhattarai, R.C. Munankarmy and Y.G. Khadka. 2002. Strategies for soil fertility research in the hills of Nepal. Kathmandu: Soil Science Division, Nepal Agriculture Research Council. Hill Agriculture Research Project.

Pearson, T.R., S.L. Brown, and R.A. Birdsey. 2007. Measurement guidelines for the sequestration of forest carbon: general technical report. USDA General Technical Report NRS-18. USDA, PA.

Rasse D.P., J. Mulder, C. Moni and C. Chenu. 2006. Carbon turnover kinetics with depth in a French loamy soil. Soil Science Society of America Journal 70(6):20972105.

Regmi B.D., C. Poudel, B.P. Tripathi, S. Schulz and B.K. Dhital. 2005. Managing soil fertility problems of marginal agricultural lands through integrated plant nutrient systems: Experiences from the hills of Nepal. In: Proceedings of International Workshop on Micronutrients in South and Southeast Asia (8-11 September 2004). Kathmandu, Nepal. Pp 109-119.

Shrestha B.M, B.K.Sitaula, B.R. Singh and R.M. Bajracharya. 2004. Soil organic carbon stocks in soil aggregates under different land use systems in Nepal. Nutritional Cycle Agroecosystems 70 (2):201-213.

Shrestha, B.M. and B.R. Singh. 2008. Soil and vegetation carbon pools in a mountainous watershed of Nepal. Nutritional Cycle Agroecosystem 81:179-191. Springer Science+Business Media B.V. DOI 10.1007/s10705007-9148-9.

Singh, S.P. 2007. Himalayan Forest Ecosystem Services: Incorporating in National Accounting. Central Himalayan Environment Association, Nainital, Uttarakhand, India.

Sitaula, B.K., R.M. Bajracharya and B.R. Singh. 2004. Factors Affecting Organic Carbon Dynamics in Soils of Nepal/ Himalaya Region - A Review and Analysis. Nutrient Cycling in Agro-ecosystems, 70 (2): 215-229.

SSMP. 2009. Farmer Profiles from the Mid-hills of Nepal. Helvetas - Sustainable Soil Management Programme. Document No. 151. Kathmandu, Nepal.

Upadhyay, T.P., P.L. Sankhayan and B. Solberg. 2005. A review of carbon sequestration dynamics in the Himalayan region as a function of land-use change and forest/soil degradation with special reference to Nepal. In: Agriculture, Ecosystems and Environment. 105: 449-465.

Vaidya, A., C. Turton, K.D. Joshi and J.K. Tuladhar. 1995. A system analysis of soil fertility issues in the hills of Nepal: implications for future research. In: Challenges in Mountain Resource Management in Nepal: Process, Trends and Dynamics in Middle Mountain Watersheds (Eds. H. Scheier, P.B. Shah \& S. Brown). ICIMOD/IDEC/BC, Kathmandu. Pp.63-80. 
Nepal Journal of Science and Technology Vol. 13, No. 1 (2012) 